7-1974

\title{
Crime and Deterrence: Correlation Analysis
}

\author{
William C. Bailey \\ Cleveland State University, w.bailey@csuohio.edu \\ J. David Martin \\ Lakehead University \\ Louis N. Gray \\ Washington State University
}

Follow this and additional works at: https://engagedscholarship.csuohio.edu/clsoc_crim_facpub

Part of the Criminology Commons, and the Quantitative, Qualitative, Comparative, and Historical Methodologies Commons

How does access to this work benefit you? Let us know!

Publisher's Statement

(c) 1974 Sage Publications

\section{Original Citation}

Bailey, W. C., Martin, J. D., \& Gray, L. N. (July 01, 1974). Crime and Deterrence: A Correlation Analysis. Journal of Research in Crime and Delinquency, 11, 2, 124-143.

\section{Repository Citation}

Bailey, William C.; Martin, J. David; and Gray, Louis N., "Crime and Deterrence: Correlation Analysis" (1974).

Sociology \& Criminology Faculty Publications. 67.

https://engagedscholarship.csuohio.edu/clsoc_crim_facpub/67

This Article is brought to you for free and open access by the Sociology \& Criminology Department at EngagedScholarship@CSU. It has been accepted for inclusion in Sociology \& Criminology Faculty Publications by an authorized administrator of EngagedScholarship@CSU. For more information, please contact library.es@csuohio.edu. 


\title{
CRIME AND DETERRENCE: A CORRELATION ANALYSIS
}

\author{
William C. Bailey, Cleveland State University \\ J. David Martin, Lakehead University \\ Louis N. Gray, Washington State University
}

This article was originally published in:

Bailey, William C. and J. David Martin et al (1974). Crime and Deterrence: A Correlation Analysis. Journal of Research and Crime and Delinquency, 11, 124-143.

Post-print standardized by MSL Academic Endeavors, the imprint of the Michael Schwartz Library at Cleveland State University, 2013

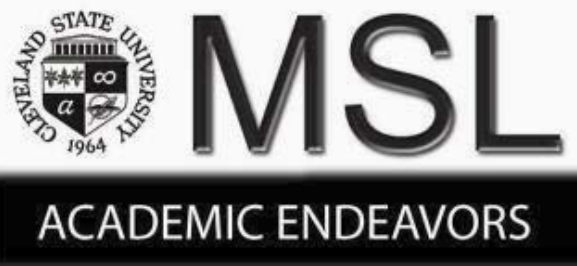




\title{
Crime and Deterrence: A Correlation Analysis
}

\author{
William C. Bailey \\ Associate Professor of Sociology, Cleveland State University \\ Ph.D. (Sociology), 1971, Washington State University \\ J. David Martin \\ Associate Professor of Sociology, Lakehead University \\ Ph.D. (Sociology), 1966, University of Washington \\ Louis N. Gray \\ Associate Professor of Sociology, Washington State University \\ Ph.D. (Sociology), 1969, University of Washington
}

A correlation analysis of the severity and certainty of punishment and offense rates for the major index crimes produces results consistent with the predictions of deterrence theory. Certainty of punishment proves to be the chief deterrent for most crimes. Homicide, however, is influenced by severity, possibly reflecting the differences between homicide and other offenses. Little evidence of interaction is found between certainty and severity in effects on crime rate. A power function proves to better describe the relationship between the punishment variables and crime rates than a rectilinear equation-a conclusion which, even apart from the date, appears more reasonable than the reverse.

$\mathrm{T}$ HE ROLE OF PUNISHMENT in social control remains a topic of discussion in the popular (Bazelon, 1960; Menninger, 1968; Clark, 1969; Wilson, 1973) and sociological literature (Zimring and Hawkins, 1973; Thorsell and Klemke, 1972; Waldo and Chiricos, 1972; Bailey and Smith, 1972; Ehrlich, 1972; Zimring, 1971; Bedau, 1970, 1971; Chiricos and Waldo, 1970; Jensen, 1969; Tittle,
1969; Ball, 1969; Gibbs, 1968; Campbell and Ross, 1968; van den Haag, 1968; Zimring and Hawkins, 1968; Chambliss, 1966, 1967). In fact, the efficacy of the death penalty in deterring capital offenses continues as one of the liveliest debates of the century (Bailey, 1973). Philosophers, theologians, legislators, and social scientists have joined in the deterrence controversy. ${ }^{1}$ Opinions on this issue

1. Discussions of deterrence are typically divided into two areas of concern: special deterrence and general deterrence. Special deterrence is concerned with reactions that the threat of punishment produces among those who have been previously punished and who, for that reason, may react to threats differently from the rest of the population. General deterrence concerns the response the threat of punishment produces among persons who have not been previously punished (Zimring, 1971). The concern of this paper is with the latter type of deterrence. For an excellent review of deterrence theory and the distinction between special and general deterrence, see Ball (1955), Andenaes (1966), and Zimring (1971) . 
seem highly polarized. In the classical criminological tradition, proponents argue the absolute necessity of punitive sanctions to deter potential lawbreakers. Some even go so far as to suggest that punishment and the fear of punishment are the solution to the entire crime problem. Witness, for example, a statement by one of the country's leading police officials in addressing the police's understanding of the crime problem:

They alone know the answer to the crime problem. That answer can be summed up in one sentence-adequate detection, swift apprehension, and certain, unrelenting punishment. That is what the criminal fears. That is what he understands, and nothing else, and that fear is the only thing which will force him into the ranks of the law-abiding (Hoover, 1936).

At the other extreme there are those who see no hope whatsoever of punishing people into conformity. Positivist criminologists have been most vocal in this respect. They argue that an examination of the history of punishment clearly reveals its ineffectiveness in controlling crime. Barnes and Teeters, for example, state:

Not a single assumption underlying the theory of capital punishment can be squared with the facts about human nature and social conduct that have been established through the progress of science and sociological thought in the last century and a half. In fact the whole concept of capital punishment is scientifically and historically on a par with astrological medicine, the belief in witchcraft or the rejection of biological evolution (1951, 355).

Despite this evidence, they add, we continue to punish wrongdoers. Clearly, deterrence explanations of punishment are but "rationalizations of revenge." No other justification is possible (Barnes and Teeters, 1951). ${ }^{2}$

Unfortunately, much of the deterrence debate has been of a philosophical or moral nature (Gibbs, 1968; Puttkammer, 1953). Many have had much to say on this issue, but few provide any evidence to support their positions. "Moreover, much of the evidence usually cited is inadequate or inappropriate to the question at issue" (Tittle, 1969, 410) and would appear to have been collected for the sole purpose of disproving the deterrent value claimed for punishment (McClellan, 1961; Royal Commission on Capital Punishment [1949-1953], 1955).

In sum, despite the length and intensity of the deterrence controversy, the role of punishment in deterring crime remains obscure (Zimring and Hawkins, 1973). This is an alarming situation when considering that the presumed effect of punishment provides the foundation of our criminal justice system.

\section{Previous Research}

Most deterrence research of the past few decades has focused upon the relationship between homicide and capital punishment (Sellin, 1955, 1967; Savitz, 1958; Schuessler, 1952; Royal Commission on Capital Punishment [1949-1953], 1955). Investigations in this area have been of two sorts. First, historical analyses have been conducted comparing the incidence of homicide before and after the aboli-

2. Equally negative, but less flamboyant, conclusions about punishment as a deterrent to crime may be readily found in more recent criminology texts as well. See, for example, Reckless $(1973,355)$, "it (punishment) does not prevent crime in others or prevent relapse into crime." 
tion or enactment of capital punishment. On an international scale such investigations have usually concluded that homicide rates and the death penalty are independent of one another (Royal Commission on Capital Punishment [1949-1953], 1955; Schuessler, 1952). Sellin's longitudinal investigation of states in this country led him to a similar conclusion: "There is no clear evidence in any of the figures we have examined that the abolition of capital punishment has led to an increase in the homicide rate, or that its reintroduction has led to its fall" (1961, 70).

The second major source of evidence relating capital punishment and homicide has come from comparisons of abolitionist and capital punishment states' murder rates. These comparisons have revealed that the rate of homicide is about two to three times higher in capital punishment than abolitionist states (Sutherland and Cressey, 1970; Schuessler, 1952). This is clearly contrary to what deterrence theory would predict. Some have argued, however, that such comparisons are invalid, for the grouping of these two types of states is not uniform with respect to possible important etiological factors; i.e., population composition, social structure, and cultural patterns. To meet this objection, Schuessler (1952) compared the homicide rates of capital punishment states with their contiguous abolitionist neighbors. This comparison revealed that states' homicide rates are indifferent to the presence or absence of capital punishment statutes (Schuessler, 1952). Further, when the risk of execution in capital punishment states was compared with homicide rates, no significant relationship was found "between a large number of executions, small number of executions, continuous executions, no executions, and what happens to the homicide rate" (Sellin, 1961, 71).

In sum, it has generally been concluded from studies of capital punishment and homicide that the death penalty is ineffective in deterring this offense; and, further, that punishment in general is ineffective in deterring all offenses. Gibbs (1968) and Van den Haag (1968) take issue with both of these conclusions. First, most investigations of homicide and capital punishment have been quite limited in scope. Essential aspects of deterrence theory have been ignored in these investigations. For example, fundamental to deterrence theory is the celerity of punishment, although empirical examination of this factor is completely absent in the literature. Second, past studies of deterrence have typically focused upon one offensehomicide-and one form of punishment - the death penalty. These studies tell us little if anything about the deterrent properties of other forms of punishment and other offenses. Obviously, general conclusions are not warranted at this time (Zimring and Hawkins, 1973).

Recent investigations have broadened the base of empirical evidence on deterrence. Gibbs (1968) examined the relationship between the severity and certainty of punishment and homicide rates for the states of this country. He hypothesized that the more certain and severe the penalties for homicide in a state, the lower the state's homicide rate would be. Estimates of the severity and certainty of punishment and offense rates were constructed from official police and prisoner statistics. ${ }^{3}$ Examination of these data revealed the relationship 
between severity and certainty of punishment and offense rates to be in the hypothesized inverse direction $(\phi=.25$ and $\phi=-.48$, respectively), with the larger coefficient between certainty and rate "entirely consistent with the position taken by practically every advocate of deterrence theory" (Gibbs, 1968, 525). In addition, Gibbs also concludes that the combined effects of the severity and certainty of punishment are additive in their effect on rates as deterrence theory would predict.

A re-analysis of Gibbs's (1968) data by Gray and Martin (1969) using a more sophisticated statistical design has led to some modifications of Gibbs's findings. These researchers examined Gibbs's data in its original ratio scale form rather than simply treating it as nominal as had Gibbs. They further examined these data by means of both a rectilinear and logarithmic statistical model. The latter correlation model was utilized because some nonlinearity was apparent in the data, and the power function has the theoretical advantage of never predicting negative crime rates, while this is possible with a rectilinear model.

Using a rectilinear model, Gray and Martin found the correlation between the severity and certainty of punishment and homicide rate to be in the hypothesized inverse direction $(\mathrm{r}=$ -.367 and $r=-.281$, respectively). The corresponding log correlations were also of a negative sign and somewhat larger $(r=-.506$ and $r=-.379$, respectively). Where Gibbs found certainty of punishment to be the more important factor, Gray and Martin found the inverse to be true. Further, a multiple correlation combining the effects of the severity and certainty of punishment on offense rates yielded correlations $(\mathrm{R}=.442$ for the linear model, and $\mathrm{R}=-.599$ for the logarithmic model) only slightly larger than the respective largest zero order correlations, thus only allowing an increment in explained variation of approximately .6 per cent and .9 per cent, respectively. In sum, contrary to Gibbs's (1968) assertion, the severity and certainty of punishment do not appear to be additive in their effect on homicide.

Tittle's (1969) deterrence investigation resembles quite closely the approach taken by Gibbs (1968). Utilizing police and prisoner statistics, he examined the relationship between the certainty and severity of punishment and offense rates for seven major felonies. ${ }^{4}$ The correlation between esti-

3. Gibbs operationalized his certainty of punishment measure as the number of persons in each state sent to prison for homicide in 1960 , divided by the total number of homicides reported to the police in that state for $1959-1960$. The severity of punishment was operationalized as "the median number of months served on a homicide sentence by all persons in prisons on December 31, 1960." The dependent variable was defined as the average annual homicide rate per one hundred thousand population for each state from 1959-1961. The average homicide rate for a three-year period was used to allow for sufficient time for the deterrent effect and to provide greater stability to the rate.

4. Tittle operationally defined the certainty of punishment as the average number of admissions to prison for each of the index offenses in each state, from 1959 to 1962, divided by the number of index offenses known to the police in each state, from 1958 to 1962 . The severity of punishment was operationalized as the mean number of months spent in prison by index crime offenders released in 1960. Tittle's "Deviance Index" consisted of the mean annual number of index offenses reported to the police in each state per 100,000 population from 1959 to 1963 . 
mates of the certainty of punishment and offense rates for all seven offenses combined was found to be in the predicted direction (Tau $c=-.45$ ). For the individual offenses the coefficients are: sex offenses $=-.17$; assault $=-.46 ;$ larceny $=-.37$; robbery $=$ -.36 ; burglary $=-.31$; homicide $=$ -.17 ; and auto theft $=-.08$. Like the total crime index, each of these coefficients is in the hypothesized direction, and with the exception of those for homicide and auto theft, are highly significant $(\mathrm{P}<.0 \mathrm{I})$.

The relationship between the severity of punishment and offense rates for all offenses combined was found to be Tau $c=.14$. For the individual offenses the correlations are: sex offenses $=.26$; assault $=.18$; larceny $=$ .14 ; robbery $=.05$; burglary $=.14$; homicide $=.45$; and auto theft $=.04$. With the exception of homicide these findings are quite contrary to what deterrence theory would predict.

In a recent investigation, Chiricos and Waldo (1970) provide a further examination of the hypothesis that rates of crime are inversely related to the certainty and severity of punishment. Like Tittle (1969), they examine the deterrence hypothesis for each of the major index crimes, but for three points in time. 5 Further, they examine the relationship between changes in the level of the certainty and severity of punishment and their effect on offense rates. ${ }^{6}$ As in Gibbs's (1968) and Tittle's (1969) investigations, official police and prisoner statistics were used to construct punishment and rate indexes.

Examination of the certainty-rate data revealed that all but one correlation was in the hypothesized negative direction. The strength and level of significance of the associations varied greatly by offense and over time, however. Only for assault were the two variables consistently and significantly related for all three years. For burglary, the relationships were found to be statistically significant for two years, while the remaining correlations were either low or not consistent by offense.

The severity-rate data also provided no consistent support for the deterrence hypothesis. With one exception (homicide, 1960), all correlations were either positive or low negative. Moreover, little consistency over time was exhibited within offense categories.

Examination of changes in the levels of the severity and certainty of punishment and their effect on offense rates

5. Chiricos and Waldo's operationalization of the certainty and severity of punishment is as follows:

$19 \mathrm{XX}$ certainty $=19 \mathrm{XX}$ Admissions to Prison for "X" Offenses Mean of "X" Crimes Known to Police in 19XX and 19XX

$19 X X$ severity $=$ Median Length of Sentence Served by State Prisoners Released in 19XX

Crime rates were calculated on the basis of three year averages: mean of 1950, 1951, and 1952 rates; mean of 1960,1961 , and 1962 rates; and mean of 1963,1964 , and 1965 rates.

6. Chiricos and Waldo calculated changes in the levels of the severity, certainty, and offense rates as follows:

$19 \mathrm{XX}-19 \mathrm{YY} \%$ Change in Certainty $=\underline{(19 \mathrm{YY} \text { certainty })-(19 \mathrm{XX} \text { certainty })}$

$$
19 \times X \text { certainty }
$$

$19 \mathrm{XX}-19 \mathrm{YY} \%$ Change in Severity $=(19 \mathrm{YY}$ severity $)-(19 \mathrm{XX}$ severity $)$

$$
\text { 19XX severity }
$$

$19 \mathrm{XX}-19 \mathrm{YY} \%$ Change in Rate $=\underline{(19 \mathrm{YY} \text { rate })-(19 \mathrm{XX} \text { rate })}$ 
also produced inconsistent findings. Only approximately 4 per cent of the certainty-rate correlations were in the hypothesized direction and statistically significant, while none of the severity-rate correlations was as hypothesized and statistically significant. Chiricos and Waldo conclude that their data provide little evidence of deterrence. ${ }^{7}$

In a final investigation of note, Ehrlich (1972) also examines the hypothesis of a negative relationship between the severity and certainty of punishment and offense rates for the major index crimes for 1940, 1950, and 1960. Using punishment and rate indexes quite similar to those of the above investigators, he reports a consistent negative correlation (r) between severity and rate, averaging (1940-1960) as follows for each offense: robbery $=-.325$; burglary $=-.546$; larceny $=-.287 ;$ auto theft $=-.174$; murder $=-.214$; rape $=-1.88$; assault $=-.389 . .^{8}$ Similarly, the association between certainty and rate was also found to be consistently in the hypothesized direction with coefficients averaging: robbery $=-.913$; burglary $=-.468 ;$ larceny $=-.298$; auto theft
$=-.247 ;$ murder $=-.466 ;$ rape $=$ -.578 ; assault $=-.393$.

In addition, Ehrlich also reports that when median family income, percentage of families below one half of the median family income, and percentage nonwhite are introduced as control variables (all three factors are described by Ehrlich as "major theoretical determinants of criminal activity"), the relationship between punishment and rate remains generally unchanged. ${ }^{9}$

In spite of the shortcomings of police and prisoner statistics used to construct his punishment and rate indexes and the somewhat stringent econometric specification of functional relationships required in the regression model used, Ehrlich (1972, 275) concludes that his data are "consistent with the hypothesis that law-enforcement activity has a deterrent effect on offenders." Furthermore, the fact that coefficients for crimes against persons are not on the average lower than for crimes against property suggests that contrary to common belief, "law-enforcement activity may not be less effective in combating crimes of hate

7. Chiricos and Waldo are reluctant, however, to suggest that the severity and certainty of punishment fail to deter crime. Rather, they question whether deterrence may be adequately addressed through the use of police and prisoner statistics.

8. Ehrlich operationalized his certainty of punishment measure as the number of persons sent to prison in each state for each of the index crimes $(1940,1950,1960)$, divided by the number of index crimes reported to the police for these years. It is not clear whether Ehrlich uses the mean or median length of sentence served by released felons as his measure of severity, for he fails to reference the source of his prisoner data. He simply describes his severity measure as the "average" length of prison sentence.

9. Although Ehrlich should be commended for introducing these three socio-economic variables into his investigation, it is unclear from his analysis how each of these factors individually, or in combination, affects the relationship between the severity and certainty of punishment and offense rates. Unfortunately, he solely reports overall partial coefficients between his punishment and rate variables, combining the effects of all three socio-economic factors. A much more comprehensive picture might have been revealed had he reported (a) zero order correlations between each of the independent variables and rate. (b) partial coefficients between the punishment variables and rate, controlling for each socio-economic factor, and (c) overall partial correlations between the independent and dependent variables, controlling for the combined effect of all three socio-economic factors. 
and passion than crimes involving material gain" (274).

It is of interest to note the dissimilarity of Gibbs (1968), Gray and Martin (1969), Tittle (1969), Chiricos and Waldo (1970), and Ehrlich's (1972) findings on the question of deterrence. These differences provide a particular mystery considering the similarity of the researcher's operationalizations of their punishment and rate variables, and the time periods examined. Clearly, further investigation would appear warranted.

\section{The Present Investigation}

The research reported here is a further examination of the relationship between the severity and certainty of punishment and offense rates. Our approach is similar to that of Gibbs (1968), Tittle (1969), Chiricos and Waldo (1970), and Ehrlich (1972), with the following additions: first, police and prisoner data are examined in their original ratio scale form, and not simply dichotomized or trichotomized with a resulting loss in the precision of the data. Second, the question of the additive effects of the severity and certainty of punishment on offense rates are examined for eight index offenses. Third, the relationship between the severity, certainty, and offense rate variables are examined by way of both a rectilinear and $\log$ arithmic statistical model for all eight index crimes. ${ }^{10}$ Lastly, each of the above relationships is examined over three points in time-1950, 1960, and 1964.

In line with deterrence theory the following hypotheses are advanced:

1. A substantial negative correlation exists between states' offense rates and the severity of punishment for each of the index offenses.

2. A substantial negative correlation exists between states' offense rates and the certainty of punishment for each of the index offenses.

\section{Research Method}

In order to examine the above relationships, indexes were constructed for the severity, certainty, and offense rate variables. A discussion of these indexes, the population under investigation, and the data gathering and processing techniques used follow.

\section{The Population}

The population for this investigation consists of the states of the United States. It was not possible, however, to secure complete population data for the three time periods chosen. For 1950, Michigan and Georgia failed to report the prisoner data needed for the severity ${ }^{11}$ and certainty ${ }^{12}$ indexes.

10. A discussion of the rectilinear and $\log$ statistical models will follow later in this paper.

11. Severity data were gathered from the following sources:

1951 "National Prisoner Statistics: Prisoners Released from State and Federal Institutions, 1951." Washington, D.C.: 24-27.

1960 "National Prisoner Statistics: Characteristics of State Prisoners, 1960." Washington, D.C.: 69.

1964 "National Prisoner Statistics: State Prisoners: Admissions and Releases, 1964." Washington, D.C.: 52 .

12. Police and prisoner statistics were used to construct the certainty of punishment measure.

The sources of these data are as follows:

Federal Bureau of Investigation

1950 "Crime in the United States: Uniform Crime Reports-1950." Washington, D.C.: 78-82. 1960 "Crime in the United States: Uniform Crime Reports-1960." Washington, D.C. 34-37. 1964 "Crime in the United States: Uniform Crime Reports-1964." Washington, D.C.: 50-53. 
For 1960 , New Jersey failed to report the needed data, as did New Jersey and Alaska for 1964. This left a total of 46 states for 1950, 47 states for 1960 , and 48 states for 1964. It is not possible at this time to say why these prisoner data were not available for the states and years mentioned. These states are simply excluded from tables reporting such data with a note stating, for example, "Excludes statistics for Georgia and Michigan." Repeated inquiries to the Federal Bureau of Prisons about this matter have resulted in no explanation.

\section{Measures}

\section{The Certainty of Punishment.-} The certainty-of-punishment measure used consists of the number of admissions to state prisons for each of the index offenses divided by the number of such crimes reported to the police. This measure produced a certainty of punishment value for each offense for the states and years designated above. This measure would appear as follows for the three time periods designated:

\section{Certainty $=$}

\# admissions to prison for offense " $\mathrm{X}$ "

Official police and prisoner statistics were used in the construction of this measure. ${ }^{13}$

The above equation yields a certainty of punishment value which can range theoretically from zero to one. A value of zero would indicate that no one was convicted and imprisoned for the offense in question, while a value of one would suggest that an equal number of convictions and offenses were reported. It should be kept clearly in mind that certainty estimates cannot be interpreted as the proportion of offenders who are convicted and imprisoned. Such data on individual offenders, while preferable, are simply not available.

A second difficulty with this measure was discovered when comparing number of prison admissions for various offenses with the number of such offenses reported to the police. In some instances, it was found that there were more admissions to prison for an offense than there were such offenses reported. That is, the numerator of our certainty index was found to be larger than the denominator, thus yielding a certainty value greater than unity. This situation could have occurred as a result of: (1) police departments in the states in question underreporting the number of such offenses; (2) prison authorities inaccurately reporting the number of prison admissions for these offenses; (3) plea bargaining (persons being imprisoned for offenses other than those reported by the police); (4) imprisonment of persons whose offenses were committed and reported during a previous year; or (5) any combination of these. In the 30 cases where this situation occurred $(1950=20$, $1960=10,1964=0)$ a certainty value of .9999 was assigned.

Federal Bureau of Prisons

1950 "National Prisoner Statistics: Prisoners in State and Federal Institutions, 1950." Washington, D.C.: 72-73.

1960 "National Prisoner Statistics: Characteristics of State Prisoners, 1960." Washington, D.C." 16-18.

1964 "National Prisoner Statistics: State Prisoners: Admissions and Releases, 1964." Washington. D.C.: 17.

13. The sources of these data are reported in note 12 supra. 
As indicated earlier, data were not available for all states for some years. In addition, complete prisoner data were also not available for all states for all offenses included in the analysis. In the tables where missing prisoner data would normally be reported, one finds a dash $(-) \cdot{ }^{14}$ It is not clear what this dash means, for there are no footnotes describing this symbol. The same symbol appears elsewhere in Bureau of Prisons publications where frequencies are too small ( $\mathrm{n}<10$ or 12 ) to compute meaningful averages. In the tables being considered here, however, we are dealing with frequencies, and a small $\mathrm{n}$ size is not a consideration. It would thus appear that the dash $(-)$ is used to symbolize either (1) that no persons were sent to prison in these states for these offenses (a zero frequency), or (2) that no data were reported by these states on prison admissions for these offenses and years. The first explanation seems more plausible, for no zero frequencies are reported in these data. Inquiry of the Federal Bureau of Prisons as to the meaning of this symbol (-) has received no satisfactory response to date. Consequently, 25 state-by-offense categories (13 for 1950, 8 for 1960, and 4 for 1964) were omitted from the analysis.

A further difficulty with these data centers in the problem of compara- bility of offense categories. The index offenses examined for 1950 include murder, manslaughter, robbery, rape, larceny, auto theft, burglary, and aggravated assault. Prisoner data for 1950 are comparable. For 1960 and 1964, however, no prisoner data are reported for manslaughter or rape. Consequently, these offenses were omitted from the 1960 and 1964 analyses. ${ }^{16}$

Three additional limitations of our certainty measure should also be briefly noted. First, this measure is narrow in scope. It refers solely to the certainty of imprisonment, ignoring other types of penalties. It should also be kept in mind, however, that each of the offenses considered here is a major felony, generally punishable by at least one year in prison. Secondly, our measure does not take into account the commission of multiple offenses by persons (Tittle, 1969) or problems associated with "plea bargaining."

Third, because of delays between arrest and trial, many persons arrested for an offense during any given year may not be imprisoned (if convicted) until the following year. To control for this time lag factor, it would seem advisable to either (a) compare offense rates for 1950,1960 , and 1964 (the denominator of the certainty index) with prison admis-

14. This symbol appears for the following offenses by year:

1950 manslaughter (3), auto theft (8), rape (2)

1960 auto theft (8)

1964 auto theft (8), larceny (1)

15. In addition, data from the Uniform Crime Reports for 1960 and 1964 exclude criminally negligent manslaughter. This offense, however, is evidently included in prisoner homicide data for these two years. Further, the assault categories for the prisoner and offense rate data are not completely comparable. For 1960 and 1964, this offense was categorized for the prisoner data as "assault." Offense rate data are available only for "aggravated assault" for these years. Despite this discrepancy, this offense was left in the analysis. "Assault" data were used in the numerator of our certainty equation, while "aggravated assault" data were used in the denominator. This would have the effect of escalating certainty values for this offense. This would be a constant factor, however, for all states. 
sion figures for the following years, 1951, 1961, and 1965 (the numerator of the certainty index) or (b) average prison admission figures for 1950-51, 1960-61, and 1964-65 for the numerator of our measure. In the absence of comparable prison admission figures for 1951, 1961, and 1965, however, neither adjustment is possible. Accordingly, it must be assumed that the carry-over of cases from year to year between arrest and imprisonment is a constant factor, thus not substantially biasing our certainty index. ${ }^{16}$

While it does suffer from the difficulties indicated, the certainty index does reflect, although with error, the relative certainty of punishment in different states. Assuming the error to be random relative to crime rates, such error will only serve to attentuate any "genuine" correlation between certainty and rate.

The Severity of Punishment.-Severity of punishment is operationally defined here as the median number of months served in prison by released felons. These data were obtained from statistics published by the Federal Bureau of Prisons for 1951, 1960, and 1964. This measure differs from that used by Tittle (1969), who used the mean length of sentence served (in months) rather than the median. It also differs from that used by Gibbs (1968), who used the median number of months served by felony prisoners as of December 31, 1960.17 The me- dian was used here because data comparable to either Gibbs's or Tittle's were not available for all three time periods.

Like the certainty of punishment data discussed above, statistics on the severity of punishment were also found to be incomplete. ${ }^{18}$ First, severity figures (median length of sentence) were not available for 1950. Apparently, the Federal Bureau of Prisons did not request these data from the states that year. Severity data were compiled for 1951, however. These data were used as an estimate of 1950 severity. It was felt that these figures would provide an adequate estimate for the former year. Further, it was believed important to examine the severity-rate relationship over three rather than just two points in time (1960 and 1964).

Second, like the certainty data, published severity statistics are incomplete. For 1951, 17 severity figures are not reported. This resulted from the fact that no prisoners were released from prison in some states for these offenses in 1951. Data were also missing for 1960 and 1964, when the median length of sentence was not reported for offense categories where fewer than ten persons were released. For 1960 and 1964 this amounted to 31 and 36 missing cases, respectively. ${ }^{19}$ It was not possible to secure comparable severity data for 1959 or 1961 , or for 1963 or 1965 , to calculate estimates for these missing cases. ${ }^{20}$

16. For a discussion of two alternative measures of certainty ("clearance rate" and "arrest rate") and the problems associated with each, see Zimring and Hawkins (1973, 330-335).

17. See note 8 supra for a discussion of Ehrlich's severity index.

18. See note 11 supra for the source of these data.

19. Data were missing for the following offenses by year: 1960 homicide (9), robbery (4), assault (7), larceny (4), auto theft (7) 1964 homicide (11), robbery (4), assault (7), auto theft (14)

20. In addition, exact severity figures were not provided for offenses whose median severity was over 180 months. These included 1960 homicide (2); 1964 homicide (8), robbery (3). These offenses were assigned a value of 180 months. 
One final possible difficulty with our severity of punishment measure concerns the question of how well the average length of prison sentence served by released felons in 1951, 1960, and 1964 reflects the courts' sentencing practices for these years? That is, do these figures provide a good indicator of the length of prison sentence a felon might expect if convicted during these years? Unfortunately, in the absence of adequate court statistics it is not possible to directly test this question. ${ }^{21}$ Inspection of figures in Table 1 , however, indicates that with the exception of one offense (homicide), sentencing practices were relatively constant for the 14-year period considered here. Again, unfortunately, comparable prisoner statistics for more recent years (after 1964) are not available to test whether this trend has continued.

\section{TABLE 1}

Median Length of Prison Sentence (Months) Served by Released Felons, by YeAR AND OfFENSE

\begin{tabular}{llll}
\hline \multicolumn{1}{c}{ Offense } & 1951 & 1960 & 1964 \\
\cline { 1 - 2 } $\begin{array}{llll}\text { Murdor and Nonneg- } \\
\text { ligent Manslaughter }\end{array}$ & 97 & 52 & 49 \\
Robbery & 33 & 34 & 36 \\
A ssault & 22 & 20 & 21 \\
Eurglary & 22 & 20 & 20 \\
Larceny & 17 & 17 & 17 \\
Auto Theft & 20 & 19 & 18 \\
\hline
\end{tabular}

Source: See note 11.
Crime Rate: The Dependent Variable.-The dependent variable of this investigation consists of each state's crime rates for the offenses and years specified above. Crime rate is here defined as the number of offenses reported to the police per $100,000 \mathrm{popu}$ lation. These data were obtained from the Federal Bureau of Investigation's Uniform Crime Reports for 1950, 1960, and 1964. ${ }^{22}$ Rate figures were available for all states for each of the offenses and years selected.

Rate data were gathered for all three time periods for homicide, robbery, burglary, assault, larceny, and auto theft. In addition, for 1950, figures were also gathered for rape and manslaughter. Comparable severity and certainty data were not available for these two offenses for 1960 and 1964, however.

Although FBI statistics have provided the most commonly used source of data in deterrence investigations, they are not without their faults. Most notable of these concern problems of incompleteness and comparability of offense categories. At the one extreme, there are those who view these difficulties as so serious as to preclude their use in criminological investigations (Ahern, 1971). Most students of crime, however, argue that the data may not be good, but they are the best we have for many purposes and may be used very profitably if one keeps in mind their limitations. For an excellent discussion and critique of the Uniform Crime Reports, see Wolfgang, 1958, 1963; Beattie, 1960; Chilton, 1966; Lejins, 1966. ${ }^{23}$

21. The latest figures (1970) issued by the Federal Bureau of Prisons on released felons cover only 33 of the 50 states. Furthermore, the form of the data reported does not permit calculation of the median (or mean) length of sentence served in each state for each of the major felonies (Federal Bureau of Prisons, 1970, 45-56).

22. For the source of these offense rate data, see note 12 supra.

23. For a more detailed discussion of the problems of police statistics in conducting deterrence research, see Ehrlich (1972) and Zimring and Hawkins (1973). 


\section{Data Processing and Analysis}

The measures of association used in this analysis are the Pearson product moment correlation $(r)$ and multiple $R$. The only assumption necessary to use these measures is that one's data reach at least an interval level of measurement. This assumption would appear warranted for our data.

Tittle (1969), Gibbs (1968), and Waldo (1970) were not (apparently) willing to assume their data were of an interval level of measurement. Gibbs, as we recall, utilized a conventional $\phi$ analysis, dichotomizing his data at the median. He felt his data did not meet the assumption of normality. Gray and Martin (1969) point out that this assumption is not required in order to use $r$ or $R$ as a measure of association, but only if one is interested in using tests of significance in order to make a population inference. Gibbs's data, as we recall, were for all practical purposes population data. Some might argue that the possible unreliability of police statistics does not allow an interval level of measurement to be assumed. The possible unreliability of police data is not negated by reducing one's level of measurement, however. In short, the type of statistical design used by Gibbs (1968), Tittle (1969), and Chiricos and Waldo (1970) results in a substantial loss in the precision of the punishment and rate data. ${ }^{24}$

\section{Alternative Models and Decision-making}

Gray and Martin (1969) found that a power function relating severity and certainty of punishment best explained Gibbs's (1968) homicide data. The usual model in a correlation analysis of this kind is of the form $Y=$ $\mathrm{A}+\mathrm{Bx}$. Both a rectilinear and curvilinear correlation model will be examined here, for a single instance in which the power function proves superior may be atypical.

The power function is expressed by taking the logarithms of all three variables and computing the conventional Pearson product-moment correlation coefficients. The rectilinear model is expressed by computing the same correlation coefficients with the raw data. The model with the higher $r$ value has the better fit for a particular set of data; that is, the rectilinear model is the model of better fit if the raw data produce higher coefficients than the logarithmic data, while the power function is the model of better fit if the reverse occurs. ${ }^{25}$

For various reasons conventional "tests of statistical significance" are not appropriate for these correlation coefficients. Important assumptions required by the tests-most notably, independent random sampling-cannot be met. ${ }^{26}$ Consequently, we have arbitrarily chosen to regard as "large" any coefficient whose absolute value

24. The statistical design used here has the further advantage over that used by Gibbs and Tittle of being able to examine the simultaneous relationship between three or more variables, interaction among variables, and the form of the relationship between variables.

25. In much correlation analysis in criminology it is uncritically assumed that the form of the relationship between independent and dependent variables is linear and can best be described with a straight regression line. Unfortunately this "rule of thumb" of linearity has caused investigators to overlook the possible usefulness of alternative correlation models. Recently, however, the linearity of relationships between punishment and rate variables in deterrence research has been seriously questioned, with alternative (curvilinear) correlation models being used quite profitably (Gray and Martin [1969], Bailey and Smith [1972]). For a discussion of linear and nonlinear relationships in correlation analysis see any introductory statistics text. 
exceeds .500 and as "moderate" any coefficient between .400 and .500. Correlations whose value falls below .400 will arbitrarily be called "low."

\section{Results}

Table 2 reports index correlations between punishment variables and crime rates. These correlations are based on the assumption that the association between the variables is rectilinear in form.

\section{TABLE 2}

Index Correlations between Punishment Variables and Selected Offense Rates, BY YEAR

\begin{tabular}{|c|c|c|c|c|}
\hline & Punishment & Product & Moment $\mathrm{C}$ & Correlation \\
\hline Offense & Varfable & 1950 & 1960 & $\quad 1954$ \\
\hline Homicicle & $\begin{array}{l}\text { Severity } \\
\text { Certainty } \\
\text { Nultiple }\end{array}$ & $\begin{array}{r}-.396 \\
.120 \\
.402\end{array}$ & $\begin{array}{r}-.332 \\
-.366 \\
.450\end{array}$ & $\begin{array}{r}-.165 \\
-.228 \\
.288\end{array}$ \\
\hline Robbery & $\begin{array}{l}\text { Soverity } \\
\text { Certainty } \\
\text { Multiple }\end{array}$ & $\begin{array}{r}-.125 \\
-.446 \\
.487\end{array}$ & $\begin{array}{r}-.112 \\
-.471 \\
.480\end{array}$ & $\begin{array}{r}-.068 \\
-.338 \\
.372\end{array}$ \\
\hline Assau $1 t$ & $\begin{array}{l}\text { Severity } \\
\text { Certainty } \\
\text { Multiple }\end{array}$ & $\begin{array}{r}.017 \\
-.365 \\
.374\end{array}$ & $\begin{array}{r}.150 \\
-.370 \\
.370\end{array}$ & $\begin{array}{r}.087 \\
-.401 \\
.415\end{array}$ \\
\hline Burglary & $\begin{array}{l}\text { Severity } \\
\text { Certainty } \\
\text { Multiple }\end{array}$ & $\begin{array}{r}-.040 \\
-.121 \\
.148\end{array}$ & $\begin{array}{r}.158 \\
-.448 \\
.449\end{array}$ & $\begin{array}{r}.271 \\
-.527 \\
.529\end{array}$ \\
\hline Theft & $\begin{array}{l}\text { Severity } \\
\text { Certainty } \\
\text { Multiple }\end{array}$ & $\begin{array}{r}-.041 \\
-.247 \\
.261\end{array}$ & $\begin{array}{r}.191 \\
-.377 \\
.379\end{array}$ & $\begin{array}{r}.105 \\
-.450 \\
.459\end{array}$ \\
\hline Auto Theft & $\begin{array}{l}\text { Severity } \\
\text { Certainty } \\
\text { Multipje }\end{array}$ & $\begin{array}{r}-.086 \\
-.251 \\
.262\end{array}$ & $\begin{array}{r}.295 \\
-.378 \\
.426\end{array}$ & $\begin{array}{r}.194 \\
-.528 \\
.532\end{array}$ \\
\hline $\begin{array}{l}\text { Man- } \\
\text { slaughter }\end{array}$ & $\begin{array}{l}\text { Severity } \\
\text { Certainty } \\
\text { Multiple }\end{array}$ & $\begin{array}{r}-.144 \\
-.153 \\
.213\end{array}$ & & \\
\hline Rape & $\begin{array}{l}\text { Severity } \\
\text { Certainty } \\
\text { Multiple }\end{array}$ & $\begin{array}{r}-.006 \\
-.654 \\
.654\end{array}$ & & \\
\hline
\end{tabular}

We find that of the 40 correlations presented, ${ }^{27}$ three are large correlations and five are moderate correla- tions, for a total of eight correlations which meet our criteria for further attention. All are negative, and all involve certainty. The probability of all eight correlations having the same sign (under the null hypothesis that positive and negative correlations are equally likely) is equal to $2\left(2^{-8}\right)$, or .008 , thus rejecting the null hypothesis.

One additional coefficient, involving severity and homicide for 1950, just meets our criterion for "moderate correlation" when rounded to two digits. The largest positive correlation (between severity and auto theft for

\section{TABLE 3}

Log. Correlations between Punishment Variables and SeleEcted Offense Rates, BY YEAR

\begin{tabular}{|c|c|c|c|c|}
\hline \multirow[b]{2}{*}{ offeuse } & \multirow{2}{*}{$\begin{array}{l}\text { Punistument } \\
\text { Variabie }\end{array}$} & \multicolumn{3}{|c|}{$\begin{array}{l}\text { Product-moment Correlations } \\
\text { of Lopart thms }\end{array}$} \\
\hline & & 1950 & 1960 & 1964 \\
\hline Honicide & $\begin{array}{l}\text { Severity } \\
\text { Certainty } \\
\text { Multiple }\end{array}$ & $\begin{array}{r}-.044 \\
.042 \\
.058\end{array}$ & $\begin{array}{l}-.415 \\
-.349 \\
-.530\end{array}$ & $\begin{array}{l}-.009 \\
-.311 \\
-.325\end{array}$ \\
\hline Robbery & $\begin{array}{l}\text { Severity } \\
\text { Certainty } \\
\text { sultiple }\end{array}$ & $\begin{array}{r}.002 \\
-.507 \\
.535\end{array}$ & $\begin{array}{r}.020 \\
-.499 \\
.500\end{array}$ & $\begin{array}{r}.122 \\
-.639 \\
.687\end{array}$ \\
\hline Assault & $\begin{array}{l}\text { Severity } \\
\text { Certainty } \\
\text { MuItiple }\end{array}$ & $\begin{array}{r}.070 \\
-.649 \\
.687\end{array}$ & $\begin{array}{r}.333 \\
-.704 \\
.718\end{array}$ & $\begin{array}{r}.308 \\
-.615 \\
.618\end{array}$ \\
\hline Burglary & $\begin{array}{l}\text { Severity } \\
\text { Certainty } \\
\text { Multiple }\end{array}$ & $\begin{array}{r}-.094 \\
.000 \\
.102\end{array}$ & $\begin{array}{r}.223 \\
-.460 \\
.460\end{array}$ & $\begin{array}{r}.291 \\
-.524 \\
.525\end{array}$ \\
\hline Theft & $\begin{array}{l}\text { Severity } \\
\text { Certainty } \\
\text { Multiple }\end{array}$ & $\begin{array}{r}.118 \\
-.156 \\
.181\end{array}$ & $\begin{array}{r}.114 \\
-.406 \\
.418\end{array}$ & $\begin{array}{r}.108 \\
-.417 \\
.424\end{array}$ \\
\hline Auto Theft & $\begin{array}{l}\text { Severity } \\
\text { Cortainty } \\
\text { Multiple }\end{array}$ & $\begin{array}{r}.158 \\
-.051 \\
.198\end{array}$ & $\begin{array}{r}.191 \\
-.490 \\
.490\end{array}$ & $\begin{array}{r}.113 \\
-.650 \\
.651\end{array}$ \\
\hline $\begin{array}{l}\text { Man- } \\
\text { slaughter }\end{array}$ & $\begin{array}{l}\text { Scverity } \\
\text { Ccrtainty } \\
\text { Multiple }\end{array}$ & $\begin{array}{r}-.025 \\
-.119 \\
.124\end{array}$ & & \\
\hline Rape & $\begin{array}{l}\text { Sevority } \\
\text { Certainty } \\
\text { Multiple }\end{array}$ & $\begin{array}{r}.080 \\
-.596 \\
.601\end{array}$ & & \\
\hline
\end{tabular}

26. Even though it is a common practice to use statistical tests of significance for "heuristic value" even when their assumptions cannot be met, they will not be used here for two reasons: (1) as noted above, for some years and offenses complete population data were not available, and (2) the years selected for this analysis were not drawn on a probability basis, but rather are the only years when reasonably complete data are available. Accordingly, population inferences become highly questionable.

27. The multiple correlations, being dependent on the severity and certainty correlations, are not counted in comparing frequencies of positive and negative correlations or in testing hypotheses of chance association. 
1960) is .295; while 14 negative correlations are of a larger absolute value.

Table 3 reports log correlations between punishment variables and crime rates. These correlations are based on the assumption that the association between the variables takes the form of a power function.

Of the 40 correlations in Table 3 , eight are large and six are of moderate size, for a total of 14 correlations which meet our criteria of importance. All are negative; one involving severity and 13 involving certainty. The probability of all 4 correlations having the same sign (if positive and negative correlations are equally as likely) is equal to $2\left(2^{-14}\right)$, or .0001 , thus rejecting the null hypothesis.

\section{Discussion}

It seems clear from the overwhelming negative trend of the larger correlations that these data give evidence of deterrence. These results are consistent with those of Tittle (1969), Gibbs (1968), Gray and Martin (1969), and Ehrlich (1972), who also report a substantial inverse relationship between their certainty and rate indexes. They are not consistent with the conclusions of Chiricos and Waldo (1971), however. Some possible reasons for the discrepancy between Chiricos and Waldo's findings and others have been discussed elsewhere (Bailey et al., 1972). It remains for us to examine the problem of "spuriousness" commonly discussed in the literature, the question of the form of relationship between crime rates and the punishment variables, and the additivity of effect of the punishment variables.

\section{The "Spuriousness Issue"}

Since all but one of our large and moderate correlations involve certainty, it may be appropriate to ask whether they are artifacts of a commonfactor situation mentioned by Tittle (1969) and emphasized by Chiricos and Waldo (1971). The factor crimes known to the police (hereinafter, C) is the denominator of the certainty ratio and the numerator of crime rate. If we represent the situation algebraically, we have:

Certainty $=\frac{\mathrm{I}}{\mathrm{C}}$ and Crime rate $=\frac{\mathrm{C}}{\mathrm{P}}$

where $I$ is the number of imprisonments and $P$ is the population size. If $\mathrm{I}, \mathrm{C}$, and $\mathrm{P}$ are independent, increases in $\mathrm{C}$ will increase Crime Rate and decrease Certainty, while decreases in $\mathrm{C}$ will do the reverse. Accidental fluctuations in $\mathrm{C}$ will thus tend to drive the Certainty-Rate correlation in a negative direction.

This problem is especially severe for Chiricos and Waldo (1971) for reasons based on their methodology. This point has been discussed in detail elsewhere (Bailey et al., 1972). It will suffice for present purposes to say that when product-moment correlation ( $r$ ) is used, the spurious "negative pressure" is relatively modest. The best available estimate of this pressure is probably Tittle's $\mathrm{r}$ of $-.07\left(\mathrm{r}^{2}=.005\right)$, which was computed from 1,000 cases of random data, and because of this large $\mathrm{n}$ is unlikely to be far off the mark. ${ }^{28}$ Because product-moment correlation capitalizes on chance, the pressure may be a bit greater for our $\mathbf{n}$ of $35-45$, but the difference will be

28. If anything, Tittle's value would appear to be farther from zero than the true value. His "data" were strictly random, while C, I, and P are actually interrelated; for an extreme example, I cannot exceed $P$ and $G$ is very unlikely to. 
slight. ${ }^{29}$ Accordingly, "negative pressure" seems unlikely to be responsible for these results.

\section{The Model of Choice}

A special concern in this investigation is the question of the form of the relationship between punishment variables and crime rates. The conventional rectilinear form is represented in Table 2, while the power function suggested by Gray and Martin (1969) is represented in Table 3. A comparison of these tables provides an answer to the question of which model better fits the data.

In 11 of the 14 cases where one or both of the tables show a correlation of moderate or large size, the larger coefficient is found in Table 3. In three cases, the larger coefficient is found in Table 2.30 Under the null hypothesis that the larger coefficient is equally likely to be found in Table 2 or Table 3 (both .5), the binomial probability of an outcome this evenly divided, with direction predicted, is $\frac{1+14+91+364}{2^{14}}=\frac{470}{16384}=.029$
That is, the null hypothesis may be rejected, indicating that the power function better fits the data.

The power function has attractive features apart from its greater ability to account for the variation in offense rates. Its predictions make intuitive sense in that it predicts proportional changes in crime rates from proportional changes in punishment variables and does not predict such absurdities as negative crime rates. Power functions have also been asserted to be the established form for psychophysical relationships (Stevens, 1970) and there is some intuitive harmony in their also being appropriate for the social psychology of deterrence. At the same time, we should recognize that a large number of other classes of functions remain unexplored. ${ }^{31}$

\section{Additivity of Effect: Certainty and Severity}

Figures in Tables 2 and 3 give little evidence that the combined effects of the severity and certainty of punishment provide a greater deterrent value than that of certainty alone. In each table, there are only 10 instances in

29. If one adds the $r^{2}$ associated with the largest positive correlation to the $r^{2}$ associated with Tittle's-.07, the sum is less than the $\mathrm{r}^{2}$ associated with the smallest negative correlation. This holds even if one doubles the magnitude of Tittle's correlation (thus quadrupling the $\left.r^{2}\right)$. For example, from Table 3:

$$
\begin{aligned}
\text { Largest positive correlation }=.333\left(\mathrm{r}^{2}=.1109\right) \\
\text { Double Tittle's correlation }=-.14\left(\mathrm{r}^{2}=.0196\right) \\
\text { Sum of determination coefficients }=.1305
\end{aligned}
$$

A similar result holds for Table 2. To the extent that the "negative pressure" is fairly represented by a product-moment $r$ as much as twice that reported by Tittle, it seems reasonable to proceed as we have done.

For both index and $\log$ correlations, the smallest "moderate" correlation represents a coefficient of determination which exceeds the coefficient of determination associated with the largest positive correlation by more than the "spurious negative pressure."

30. These three cases included one in which the values differed by .003 ; we considered regarding them as tied, but decided that the conservative procedure would be to include the case.

31. For a discussion of the possible nonlinearity of the relationship between the severity and certainty of punishment and offense rates, see Zimring and Hawkins (1973). Andenaes (1966), and Bailey and Smith (1972). 
which the combined effect of both punishment variables $(R)$ exceeds the larger of the zero-order correlations by .01 or more. ${ }^{32}$ That is, half the comparisons involve less than .01 difference between the larger zero-order correlation and the multiple correlation. Of the four cases where the multiple correlation exceeds the larger of the zero-order correlations by .05 or more, all involve homicide; three (two in Table 2 and one in Table 3) involve murder, while one (in Table 2) involves manslaughter. In all four cases both the severity-rate and certaintyrate correlations are negative. The more frequent cases, where there is little difference between the larger zero-order correlation and the multiple correlation, typically involve a negative correlation between certainty and rate and a small positive correlation between severity and rate.

We are thus inclined to conclude that the certainty of punishment has a dominant effect except for homicide and that the severity of punishment is related to crime rate largely as a result of its correlation with certainty. With modern indeterminate sentences, the offender may be relatively unable to guess the severity of his sentence until his sentence ends, for it may depend more on his behavior behind bars than on his offense. If this should be the case, severity could hardly figure importantly in deterrence. Homicides, however, more of ten lead to long minimum sentences, with authorities reluctant to release murderers soon after imprisonment.

\section{Presence of Deterrence}

From the above, it seems clear that the dominant variable in deterrence (of those examined here) is certainty. The most common pattern in both Tables 2 and 3 involves a strong or moderate negative correlation between certainty and crime rate, a weak correlation (usually positive) between severity and crime rate; and a multiple correlation between crime rate and the two punishment variables that is roughly equal to the larger zero-order correlation. Exceptions to this rule are more likely to involve a negative correlation between severity and crime rate. The most striking of these exceptions involves homicide.

It seems fair to conclude that both Gray and Martin (1969) and Tittle (1969) are correct about the effect of severity. Severity has an important effect upon homicide, but for most crimes it is relatively unimportant. Homicide appears to be a case unto itself, which seems sociologically reasonable for homicide is structurally unlike other crimes. ${ }^{33}$

Homicide is directed at a particular victim and usually results from interpersonal stress. The murderer is especially limited to one victim (while the thief may choose among many). The murderer may be seen as one who has "decided," however hastily, that the strain of tolerating a particular victim is worse than the risk of punishment. He cannot choose the victim or the jurisdiction least likely to result in imprisonment, as the thief and even the rapist can choose. It is there-

32. We refer, of course, to differences between absolute values.

33. Rape is sometimes classed as similar to homicide, but follows roughly the "standard" pattern in these data. See, e.g., Ploscowe (1968) and Svalastoga (1962). The similiarities between aggravated assault and homicide have also been noted, but the assault data also follow roughly the "standard" pattern. See, e.g., Pittman and Handy (1964) . 
fore not surprising that while other offenders may be deterred by the serious risk of imprisonment, the person who kills is influenced by the severity of sentence at risk.

\section{SUMmary}

A correlation analysis of the severity and certainty of punishment and offense rates for the major index crimes produced results consistent with the predictions of deterrence theory. There were, however, many instances in which the predicted evidence of deterrence was absent. We are thus inclined to regard these findings as possibly reflecting a multiplicity of political and legal differences in the handling of crime data and offenders which sometimes obscure the relationship between the punishment and rate variables.

Our results indicate that certainty and not the severity of punishment is the chief deterrent for most crimes. ${ }^{34}$ Homicide, however, is influenced by severity, possibly reflecting the differences between homicide and other offenses. Further, it appears that a power function better describes the relationship between the punishment variables and crime rates than a rectilinear equation-a conclusion which, even apart from the data, appears more reasonable than the reverse.

As noted above, the difficulties in using official police and prisoner data to study deterrence precisely are many. We are thus inclined to conclude that while research of the present kind is important in establishing that a process (deterrence) is occurring, its exact nature may be better addressed by an alternative methodological approach. Fundamental to deterrence theory is the notion that potential offenders' perceptions of the probability of detection and the punishment that would result-no matter how mistaken-are the key mechanisms of deterrence. Accordingly, social psychological investigations of deterrence such as those suggested by $\mathrm{Zim}$ ring and Hawkins (1968, 1973), Waldo and Chiricos (1972), Bailey et al., (1970), and Zimring (1971), focusing on how perceptions of the severity, certainty, and celerity of punishment relate to criminal behavior and how would-be offenders come to form perceptions of the probability and nature of punishment, would seem particularly fruitful. Research of this sort is currently under way by the present writers.

\section{REFERENCES}

Ahern, James $F$.

1971 Police In Trouble, New York, Hawthorn Books.

Andenaes, Johs

1966 "The General Preventive Effects of Punishment," University of Pennsylvania Law Review, 114, 949-983.

34. Deterrence advocates agree that if punishment is to act as an effective deterrent it must be administered swiftly. Studies of the celerity of punishment for both capital and noncapital offenses are completely absent from the empirical literature, however. 
Bailey, William C.

1973 "Murder and Capital Punishment: Some Further Evidence," paper presented at the annual American Sociological Association Meetings, New York.

Bailey, William C., Louis N. Gray, and J. David Martin

1972 "On Punishment and Crime (Chiricos and Waldo): Some Methodological Commentary," Social Problems, 19 (Fall), 284-289.

Bailey, William C. and Ronald W. Smith

1972 "Punishment: Its Severity and Certainty," Journal of Criminal Law, Criminology and Police Science, 63 (December) 530-539.

Ball, John

1955 "The Deterrence Concept in Criminology and Law," Journal of Criminal Law, Criminology and Police Science, 46 (September October), 347354.

Ball, Richard A.

1969 "Why Punishment Fails," American Journal of Corrections, 31, (JanuaryFebruary) : 19-21.

Barnes, Harry E. and Negley K. Teeters

1951 New Horizons in Criminology. Englewood Cliffs, N.J.: Prentice-Hall.

Bazelon, David L.

1960 "The Imperative to Punish." Atlantic Monthly 206 (July): 41-47.

Beattie, Ronald H.

1960 "Crime Statistics in the United States," Journal of Criminal Law, Criminology and Police Science, 51, (May-June) 49-56.

Bedau, Hugo A.

1970 "Deterrence and the Death Penalty: A Reconsideration," Journal of Criminal Law, Criminology and Police Science, 61 539-548.

1971 "The Death Penalty in America," Federal Probation, 35, No. 2, 32-43.

Campbell, Donald T. and Lawrence H. Ross

1968 "The Connecticut Crackdown on Speeding: Time-Series Data in Quasiexperimental Analysis," Law and Society Review 3 (August), 33-53.

Chambliss, William J.

1966 "The Deterrent Influence of Punishment," Crime and Delinquency 12 (January) 70-75.

1967 "Types of Deviance and the Effectiveness of Legal Sanctions," Wisconsin Law Review (Summer), 703-719.

Chilton, Ronald J.

1966 "Persistent Problems in Crime Statistics." paper presented at the annual American Sociological Association Meetings, Miami, Fla.

Chiricos, Theodore and Gordon Waldo

1970 "Punishment and Crime: An examination of Some Empirical Evidence," Social Problems 18 (Fall): 200-217.

Clark, Gerald

1969 "Black Tuesday in Montreal: What Happens When the Police Strike," Time Magazine (Nov. 16), 45ff

Clark, John P. and Larry L. Tifft

1966 "Polygraph and Interview Validation of Self-reported Deviant Behavior," American Socilogical Review 31 (August) : 516.

Ehrlich, Isaac

1972 "The Deterrent Effect of Criminal Law Enforcement," The Journal of Legal Studies, 1, No. 2, 259-276.

Federal Bureau of the Census

1945 Judicial Criminal Statistics. Washington, D.C. 
Federal Bureau of Investigation

1950 Crime in the United States: Uniform Crime Reports-1950. Washington, D.C.

1960 Crime in the United States: Uniform Crime Reports-1960. Washingtun, D.C.

1964 Crime in the United States: Uniform Crime Reports-1964. Washington, D.C.

Federal Bureau of Prisons

1950 National Prisoner Statistics: Prisoners in State and Federal Institutions, 1950. Washington, D.C.

1951 National Prisoner Statistics: Prisoners Released from State and Federal Institutions, 1951. Washington, D.C.

1960 National Prisoner Statistics: Characteristics of State Prisoners, 1960. Washington, D.C.

1963 National Prisoner Statistics: Prisoners in State and Federal Institutions, 1963. Washington, D.C.

1964 National Prisoner Statistics: State Prisoners: Admissions and Releases, 1964. Washington, D.C.

1970 National Prisoner Statistics: State Prisoners: Admissions and Releases, 1970. Washington, D.C.

Gibbs, Jack P.

1968 “Crime, Punishment and Deterrence," Social Science Quarterly 48 (March): 515-530.

Gray, Louis N. and J. David Martin

1969 "Punishment and Deterrence: Another Analysis of Gibbs' Data," Social Science Quarterly 49 (September): 289-295.

Hoover, J. Edgar

1936 "Patriotism and the War against Crime." An address given before the annual convention of the Daughters of the American Revolution, Washington, D.C., April 23.

Jensen, Gary F.

1969 "Crime Doesn't Pay: Correlates of Shared Misunderstanding," Social Problems 17 (Fall), 189-201.

Lejins. Peter $\mathbf{P}$.

1966 "Uniform Crime Reports," Michigan Law Review, 64 No. 6 (April) : 10011030.

McClellen, Grant S. (ed.)

1961 Capital Punishment. New York: H. W. Wilson.

Menninger, Karl

1968 "The Crime of Punishment," Saturday Review (Sept. 7) : 21-55.

Pitman, David J. and William Handy

1964 "Patterns in Criminal Aggravated Assault," Journal of Criminal Law, Criminology and Police Science, 55 (December): 462-470.

Ploscowe, Morris

1967 "Rape." Pp. 203-240 in E. Sagarin and D. J. MacNamara (eds.), Problems of Sex Behavior. New York: Crowell.

Reckless, Walter C.

1973 The Crime Problem. 2nd Edition. New York: Appleton-Century-Crofts.

Royal Commission on Capital Punishment (1949-1953)

1955 Report. Great Britain Parliament. (Papers by command, MD. 8932.) September. London: H.M. Stationery Office. 
Savitz, Leonard D.

1958 "A Study of Capital Punishment," Journal of Criminal Law and Criminology 49 (November-December): 338-341.

Schuessler, Karl

1952 "The Deterrent Influence of the Death Penalty," Annals 284 (November): $54-62$.

Sellin, Thorsten

1955 Quoted in pp. 17-24 in Royal Commission on Capital Punishment (19491953). Report. Great Britain Parliament. (Papers by command, MD. 8932) September, London: H. M. Stationery Office.

1961 Quoted in pp. 70-71 in Grant S. McClellan (ed.), Capital Punishment. New York: H. W. Wilson.

Stevens, S. S.

1970 "Neural Events and the Psychophysical Law," Science 170 (4 Dec.) 10431050.

Sutherland, Edwin H. and Donald R. Cressey

1970 Principles of Criminology. 7th Edition. Philadelphia: J. B. Lippincott.

Svalastoga, Kaare

1962 "Rape and Social Structure," Pacific Sociological Review 5 (Spring) : 48-53.

Thorsell, Bernard A. and Lloyd W. Klemke

1972 "The Labeling Process: Reinforcement and Deterrent," Law and Society Review 6 (February), 393-403.

Tittle, Charles R.

1969 "Crime Rates and Legal Sanctions," Social Problems 16 (Spring): 409-423. van den Haag, Ernest

1968 "In Defense of Punishment," Fortune Magazine 78 (December): 203-204.

Waldo, Gordon and Theodore Chiricos

1972 "Perceived Penal Sanction and Self-Reported Criminality: A Neglected Approach to Deterrence Research," Social Problems 19 (Spring) : 522-540.

Wilson, James Q.

1973 "If Every Criminal knew He Would Be Punished If Caught," New York Times Magazine (Jan. 28) : 9, 44, 52-55.

Wolfgang, Marvin E.

1958 Patterns of Criminal Homicide. New York: John Wiley.

1963 "Uniform Crime Report: A Critical Appraisal," University of Pennsylvania Law Review, 111 (April) : 708-738.

Zimring, Franklin E.

1971 Perspectives on Deterrence. Washington, D.C.: U.S. Government Printing Office.

Zimring, Frank and Gordon Hawkins

1968 "Deterrence and Marginal Groups," Journal of Research in Crime and Delinquency 5 (July) : 100-114.

1973 Deterrence: The Legal Threat in Crime Control. Chicago: University of Chicago Press. 